\title{
PERBANDINGAN PULAU BALI DAN PULAU JEJU DALAM BIDANG PARIWISATA
}

\author{
Ummul Hasanah ${ }^{1}$, Yuniastuti Eka Hapsari ${ }^{2}$ \\ ${ }^{1,2}$ Diploma Bahasa Korea/Departemen Bahasa, Seni dan Manajemen Budaya/Sekolah Vokasi, \\ Universitas Gadjah Mada, Indonesia

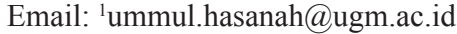 \\ Email: 2yuniastuti.eka.h@ugm.ac.id
}

\begin{abstract}
ABSTRAK
Tujuan dari penelitian ini adalah untuk memahami sejarah awal pariwisata di Bali dan Jeju dan juga untuk memahami perbedaan untuk dua pulau dalam hal pariwisata. Penelitian ini dilakukan dengan menggunakan metode studi pustaka, yaitu mengumpulkan data dari berbagai sumber referensi termasuk sumber informasi yang diperoleh dari buku dan situs internet dan wawancara langsung dengan metode informan. Kemudian data yang telah diperoleh akan diproses secara manual dan akan diuraikan secara deskriptif. Ada beberapa persamaan dan perbedaan antara Bali dan Jeju di sektor pariwisata. Persamaan dan perbedaan kedua pulau tersebut terdiri dari sejarah awal perkembangan pariwisata dan tempat wisata mereka. Bali dan Jeju keduanya menjadi terkenal di seluruh dunia karena sebuah buku yang ditulis oleh orang asing. Selain sejarah pariwisata, kedua pulau memiliki kesamaan di tempat wisata. Jika di Bali ada Desa Penglipuran, di Jeju ada Desa Seongup Jeju. Kedua desa adalah desa wisata yang masih mempertahankan budaya asli mereka. Selain kesamaan di kedua pulau ini, ada juga perbedaan Bali dan Jeju. Dimulai dengan sejarah awal perkembangan pariwisata, Pulau Bali dari awal terkenal dengan keindahan alamnya sebagai tujuan wisata, Jeju di sisi lain, perlu mengalami beberapa insiden untuk akhirnya menjadi tujuan wisata yang populer. Sedangkan untuk tempat wisata, jika dibandingkan dengan Bali, fasilitas wisata di Jeju lebih baik, misalnya di Woljeongri Beach di Jeju, wisatawan yang ingin bermain kano akan disediakan jaket keselamatan, tetapi di Sanur, Bali, pengunjung tidak diberikan fasilitas tersebut. Selain contoh-contoh itu, ada beberapa persamaan dan perbedaan lain dari kedua pulau itu.
\end{abstract}

Kata kunci: Bali, Indonesia, Jeju, Korea, pariwisata

\section{PENDAHULUAN}

Sebagai tempat wisata yang terkenal hingga mancanegara, pulau Bali memiliki sister province yaitu pulau Jeju di Korea Selatan. Sister province merupakan suatu sebutan bagi dua provinsi yang memiliki kesamaan dan sedang melaksanakan suatu kerjasama dalam bidang apapun, khususnya bidang pariwisata. Bagi masyarakat Indonesia yang mengenal Korea, banyak yang mengatakan bahwa pulau Bali merupakan pulau Jeju-nya Indonesia dan sebaliknya, masyarakat Korea mengatakan bahwa pulau Jeju merupakan pulau Balinya Korea. Hal ini karena secara garis besar, pulau Jeju dan pulau Bali memang memiliki banyak kesamaan, terutama dalam bidang pariwisata.

Pulau Jeju merupakan pulau terbesar di Korea Selatan yang terletak di ujung selatan negara Korea. Pulau Jeju dapat dikatakan sebagai tempat wisata nomor satu di Korea Selatan. Pulau jeju juga disebut dengan samda-do yang berarti "pulau yang berlimpah dengan tiga hal, yaitu bebatuan, wanita, dan angin." Selain itu, pulau Jeju merupakan sebuah pulau yang dikelilingi oleh banyak gunung, bahkan gunung tertinggi di Korea, yaitu gunung Halla terletak di pulau Jeju ini. Tidak hanya gunung, pulau Jeju juga memiliki beberapa pantai yang yang tersebar di hampIr seluruh wilayahnya. Dengan semua keindahan tersebut, pulau Jeju masuk dalam daftar UNESCO kategori Jaringan Cagar Bisofer Dunia pada tahun 2002, Situs Warisan Alam Dunia pada tahun 2007, dan Jaringan Geopark Global pada tahun 2010.

Pulau Bali dan pulau Jeju ini merupakan provinsi yang menjadi tempat wisata populer dalam negeri bagi negara masing-masing. Sama seperti pulau Bali, kini pulau Jeju lebih mengutamakan sektor pariwisata sebagai sumber pendapatan utama provinsinya. Pulau Bali dan pulau Jeju yang dikenal sebagai sister province memiliki keunikan masing-masing. Dengan berbagai persamaan dan perbedaannya, kedua pulau tersebut layak untuk dikaji dan dipelajari lebih lanjut.

\section{METODE PENELITIAN}

Dalam melaksanakan penelitian ini, digunakan metode studi pustaka dan wawancara. Metode studi 
pustaka merupakan metode pengumpulan data-data dari berbagai referensi yang meliputi pencarian sumber informasi utama dan sumber informasi tambahan yang didapat dari buku dan situs internet. Dari sumbersumber tersebut, selanjutkan digunakan sebagai data untuk menulis hasil pembahasan di penelitian ini. Sedangkan metode wawancara dilaksanakan agar bisa diketahui lebih lanjut mengenai pulau Jeju karena ketidakmungkinan untuk melakukan penelitian langsung ke pulau Jeju di Korea. Wawancara dilakukan dengan orang korea bernama Kwon Hyukjin yang pernah mengunjungi pulau Bali dan pulau Jeju. Sedangkan untuk mengetahui lebih lanjut mengenai pulau Bali, dilakukan wawancara dengan Ade Lesmana yang merupakan orang asli Bali yang pernah berkunjung ke pulau jeju.

\section{HASIL DAN PEMBAHASAN}

Pulau Bali di Indonesia dan Pulau Jeju di Korea memiliki beberapa persamaan dan perbedaan, khususnya dalam bidang pariwisata. Persamaan dan perbedaan yang dapat dilihat dari kedua pulau tersebut dilihat berdasarkan sejarah awal pariwisata dan jenis wisatanya.

\section{Berdasarkan Sejarah Awal Pariwisata}

Pulau Bali di Indonesia dan Pulau Jeju di Korea Selatan memiliki persamaan berdasarkan awal mulanya pariwisata dari kedua pulau tersebut. Pariwisata Pulau Bali dan Pulau Jeju dimulai dengan datangnya bangsa lain untuk mencari hasil alam. Para pedagang asing yang datang ke kedua pulau tersebut pada saat itu memang tidak mendapatkan hasil alam yang mereka cari, namun mereka menemukan suatu kekayaan alam lainnya yaitu sebuah keindahan alam. Dengan berbagai macam keindahan alam dan juga keramah-tamahan penduduk lokalnya, kedua pulau ini berhasil memikat hati semua orang yang berkunjung ke pulaunya.

Para pedagang yang sempat singgah di kedua pulau ini lalu menceritakan tentang keindahan kedua pulau ini melalui berbagai hasil karya. Salah satu hasil karya yang menjadikan kedua pulau ini terkenal diseluruh dunia yaitu karya tulis. Hasil karya tulis dari para seniman maupun hasil catatan seorang pedagang yang sempat berkunjung ke pulau ini lalu disebarluaskan ke seluruh penjuru negara. Pada tahun 1920, karya tulis oleh Dr. Gregor Krause yang menceritakan tentang Pulau Bali mulai tersebar di seluruh dunia. Buku ini menjelaskan keindahan Pulau Bali berikut dengan tata cara kehidupan para penduduk lokalnya. Melalui karya tulis inilah Pulau Bali menjadi terkenal di seluruh dunia. Diawali dengan karya tulis tersebutlah karya tulis mengenai keindahan Pulau Bali semakin berkembang pesat.

Sama dengan Pulau Bali, hasil karya tulis mengenai Pulau Jeju merupakan sarana yang memperkenalkan pulau ini di taraf internasional. Buku berjudul "Laporan Terombang-Ambing Hamel" yang ditulis pada tahun 1600 -an inilah yang mulai memperkenalkan Pulau Jeju ke seluruh dunia. Buku yang ditulis oleh Hamel ini selain menjelaskan tentang keindahan alam Pulau Jeju, juga menjelaskan tentang tata cara kehidupan para penduduk lokalnya. Hasil karya tulis tersebutlah yang dapat dikatakan pertama kali memperkenalkan Pulau Bali dan Pulau Jeju ke seluruh dunia. Hasil karya tersebut yang awalnya hanya menggunakan bahasa Inggris, selanjutnya lalu diterjemahkan ke bahasa lainnya untuk memudahkan para pembaca dari negara lain.

Meskipun sama-sama dikenal dunia melalui buku, awal mula pariwisata di Bali dan Jeju memiliki cerita yang berbeda. Karena keindahan alamnya, para pedagang dari luar negeri banyak yang secara tidak sengaja mempromosikan pulau Pulau Bali sebagai destinasi wisata. Berbeda dengan Bali, Jeju awalnya hanya dikenalkan sebagai sebuah pulau yang ada di ujung Korea dengan segala kekayaan alamnya namun bukan sebagai tempat wisata. Jika pariwisata Bali sejak awal sudah banyak dibantu oleh konsultan internasional, pariwisata di Jeju hanya dibantu secara finansial oleh pemerintahnya.

Pariwisata Bali yang sejak awal sudah dirancang sebagai destinasi wisata bertaraf internasional inilah yang menyebabkan Bali memiliki posisi lebih tinggi dibandingkan dengan Jeju dalam pariwisata dunia. Pada awal pembangunan pariwisata Bali, Konsultan internasional seperti SCETO dari Paris banyak membantu dalam membangun kawasan wisata Nusa Dua hingga menjadi seperti sekarang ini. Berbeda dengan Bali, Jeju tidak terlalu banyak mendapat bantuan dari konsultan internasional. Namun Jeju banyak mendapat bantuan dari para investor yang bergabung dengan pemerintah lokal untuk membangun pariwisata Jeju. 


\section{Berdasarkan Jenis Wisata}

Sebagai sebuah destinasi wisata yang bertaraf internasional, Pulau Bali dan Pulau Jeju memiliki banyak persamaan dan perbedaan dalam jenis wisata yang ditawarkan. Baranekaragam jenis wisata yang ditawarkan di pulau inilah yang menjadi daya tarik utama para wisatawan. Jenis wisata yang ditawarkan oleh kedua pulau ini dapat dibagi kedalam beberapa kelompok jenis wisata.

\section{1) Wisata Budaya}

Wisata budaya merupakan salah satu wisata yang dijadikan sebagai destinasi utama dalam pariwisata. Kebudayaan asli yang memiliki keunikannya masingmasing inilah yang dijadikan daya tarik pariwisata Pulau Bali dan Pulau Jeju. Tempat wisata dibawah ini merupakan beberapa tempat wisata unggulan dari Pulau Bali dan Pulau Jeju yang memiliki beberapa persamaan sekaligus perbedaan.

\section{a. Desa Penglipuran dan Seongeup Folk Village}

Desa Penglipuran dan Seongeup Folk Village merupakan sebuah desa tradisional yang hingga saat ini masih mempertahankan keaslian arsitekturnya. Seluruh rumah yang ada di desa ini masih terjaga keasliannya dan masih dihuni hingga saat ini. Rumah yang ada di desa wisata ini cenderung sama karena memiliki desain arsitektur dan material yang cenderung sama. Di kedua desa ini, para wisatawan dapat langsung merasakan dan melihat kehidupan masyarakat Bali dan Jeju dari zaman dulu kala yang hingga kini masih dilestarikan.

Bagi para wisatawan yang ingin berkunjung ke kedua desa ini, waktu yang paling cocok adalah saat menjelang hari raya besar karena saat inilah perayaan dan kegiatan adat akan sering dilakukan. Wisatawan yang ingin merasakan tinggal di kedua desa wisata ini juga dapat menginap di beberapa rumah penduduk yang khusus disewakan menjadi homestay.

Menjadi sebuah desa tradisional yang masih menjaga keasriannya hingga sekarang membuat Desa Penglipuran dan Seoungup Folk Village menjadi salah satu destinasi wisata yang harus dikunjungi di Pulau Bali dan Pulau Jeju. Selain memiliki beberapa persamaan, kedua desa ini ternyata juga memiliki beberapa perbedaan. Dimulai dari arsitektur yang dari rumah tradisionalnya sangat jauh berbeda. Rumah yang ada di Desa Penglipuran yang merupakan rumah tradisional Bali dapat dikatakan cukup mewah dengan arsitektur dan aksesoris rumah lainnya yang harganya cukup mahal hingga saat ini. ${ }^{1}$ Berbeda dengan rumah di Desa Penglipuran, rumah tradisional yang ada di Seoungeup Folk Village cenderung lebih sederhana, dindingnya yang terbuat dari tanah liat dan atapnya dari jerami mencerminkan kehidupan di pulau ini pada zaman dahulu (Yang, 2008 : 74).

\section{b. Pura Besakih dan Yakcheonsa Temple}

Pura Besakih dan Yakcheonsa Temple merupakan dua tempat ibadah yang juga terkenal sebagai destinasi wisata andalan dari kedua pulau ini. Kedua tempat ibadah ini sama-sama merupakan tempat ibadah terbesar di provinsinya, bahkan di negaranya. Bagi para wisatawan yang ingin berwisata religi, dua tempat ini merupakan tempat yang cocok untuk dikunjungi. Bagi para pengunjung yang ingin membawa kenang-kenangan dari Pura Besakih dan Yakcheonsa Temple, dapat membeli beberapa hasil kerajinan yang banyak dijual di sekitar tempat wisata. Rata-rata barang yang dijajakan sama, yaitu gelang, kalung, gantungan kunci, dan sebagainya.

Pada dasarnya Besakih Temple dan Yakcheonsa Temple sama-sama merupakan dua tempat ibadah terbesar yang ada di Pulau Bali dan Pulau Jeju, tetapi perbedaan yang mendasar dari kedua destinasi wisata ini adalah ajaran yang dianut. Besakih Temple di Pulau Bali merupakan tempat ibadah utama bagi umat Hindu, sedangkan Yakcheonsa Temple merupakan tempat ibadah untuk umat Budha. Bila Besakih Temple merupakan pusat kegiatan dari seluruh pura yang ada di Bali (Ulung, 2009 : 23), Yakcheonsa Temple merupakan pusat studi para biksu yang ingin lebih mendalami ajaran agama Budha. Sebagai pusat studi, Yakcheonsa Temple menyediakan kuil tersendiri bagi tempat tinggal para biksu. ${ }^{2}$

\section{c. Bali Museum dan Jeju Museum}

Menjadi sebuah destinasi wisata yang kaya budaya, Pulau Bali dan Pulau Jeju memiliki sebuah museum yang menyimpan segala hal mengenai kebudayaannya. Museum Bali dan Museum Jeju merupakan museum yang sama-sama menampilkan

\footnotetext{
www://baliwisatatravel.com/desa-penglipuran/diakses pada tanggal 9 Oktober 19.00 WIB

2 www://www.jejuweekly.com/news/articleView. html?idxno=285diakses pada tanggal 9 Oktober $19.30 \mathrm{WIB}$
} 
segala jenis hal mengenai kedua pulau tersebut. Di museum ini, para wisatawan dapat meilihat berbagai koleksi yang menampilkan koleksi etnografika seperti peralatan yang digunakan pada zaman pra sejarah dan juga perkembangan seni dan budaya yang ada di pulau tersebut. Bagi para wisatawan yang ingin mengetahui sejarah Pulau Bali dan Pulau Jeju sejak zaman pra sejarah, museum ini adalah tempat yang paling cocok untuk dikunjungi (Yang, 2008 : 103).

Perbedaan Museum Bali dan museum Jeju dapat dilihat dimulai dari sisi arsitekturnya. Museum Bali yang berada tepat di jantung kota Denpasar ini memiliki arsitektur khas Bali di seluruh bangunannya, sedangkan museum Jeju memiliki arsitektur campuran tradisional dan moderen. Berbeda dengan museum Bali, sebagian besar struktur arsitektur dari bangunan museum Jeju ini merupakan bangunan modern, hanya saja atap dari museum ini berbentuk seperti atap rumah tradisional Jeju zaman dahulu yang berbentuk bulat.

Dengan bangunan keseluruhan yang berciri khas Bali, museum Bali kini tidak hanya dikunjungi untuk berwisata saja, namun kini banyak dikunjungi untuk foto pre-wedding. Memiliki latar belakang seperti kerajaan Bali zaman dulu, membuat museum ini sering dipilih untuk para calon pengantin yang ingin mengabadikan momen istimewa tersebut. Bagi para pasangan yang ingin foto pre-wedding di museum ini, hanya perlu mengeluarkan biaya sebesar Rp 150.000,- sebagai biaya tambahan. Namun jika hanya ingin berkunjung ke museum ini, perlu membayar tiket masuk sebesar Rp 5.000/orang. Sedangkan jika ingin mengunjungi museum Jeju, tidak ada biaya masuk yang harus dikeluarkan.

\section{2) Wisata Kesehatan}

Tidak hanya berwisata tetapi juga sekaligus untuk memperbaiki kesehatan kini merupakan salah satu wisata yang banyak digemari oleh para wisatawan. Sebagai destinasi pariwisata yang sudah bertaraf internasional, pulau Bali dan pulau Jeju juga memiliki wisata kesehatan yang sudah bertaraf internasional. Wisata kesehatan yang dimaksudkan adalah wisata spa atau yang lebih dikenal dengan wellness tourism. Spa yang ada di kedua pulau ini dapat dikatakan sebagai spa dengan fasilitas terbaik di dunia. Berbagai jenis spa dengan fasilitas menarik ditawarkan di kedua pulau ini.
Thermes Marins Spa yang ada di Pulau Bali merupakan salah satu spa terbaik yang ada di pulau ini, bahkan di seluruh dunia. Spa ini pernah dianugerahi penghargaan nomor satu di dunia sebagai spa terbaik dalam acara Conde Nast Traveller Readers Spa Awards pada tahun 2010. Tidak jauh berbeda dengan spa yang ada di Pulau Bali, spa yang ada di Pulau Jeju juga sudah banyak yang bertaraf internasional. Spa andalan yang ada di pulau ini adalah Swiss Perfection Wellness SPAmed. Spa yang menjadi tempat favorit kalangan kelas atas ini merupakan spa terbaik yang ada di Pulau Jeju.

Kedua spa bertaraf internasional ini memiliki beberapa keunikannya masing-masing. Thermes Marins Spa merupakan tempat spa yang bertempat di Ayana Resort. Spa ini merupakan satu-satunya spa yang memberikan pemandangan langsung kearah laut Samudra Hindia. Perawatan khusus yang ditawarkan di spa ini adalah perawatan dengan menjadikan satu perawatan badan Asia, produk timeless European dan teknologi modern yang telah disempurnakan. ${ }^{3}$

Sedikit berbeda dengan spa yang ada di Pulau Bali, Pulau Jeju memiliki spa dengan fasilitas dan keunikannya sendiri. Yongduam Haesu Spa Land merupakan salah satu spa terbaik yang ada di pulau Jeju. Spa ini berbeda dengan spa di Bali yang terkesan mewah, spa ini lebih menonjolkan spa khas Korea dengan fasilitas seperti ruang sauna yang umumnya ada di spa-spa di Korea. Spa ini juga buka 24 jam sehingga banyak juga para wisatawan yang bermalam disini. Perawatan khusus yang ditawarkan di tempat ini adalah perawatan green tea yang langsung diambil dari perkebunan green tea di pulau Jeju. ${ }^{4}$

\section{3) Wisata Olahraga}

Bagi para wisatawan yang ingin melakukan kegiatan olahraga, pulau Bali dan pulau Jeju merupakan pilihan yang cocok untuk dikunjungi. Memiliki keindahan alam yang alami dan cuaca yang bagus, membuat kedua pulau ini sangat cocok untuk dijadikan tempat wisata olahraga. Salah satu jenis olahraga yang diunggulkan di kedua pulau ini adalah olahraga golf. Sebagai destinasi wisata internasional, memiliki sebuah lapangan golf dapat dikatan sebagai

\footnotetext{
3 www.balihealthandspa.com/thermes-marins-spa-ayana-resortbali.html

4 www.//english.visitkorea.or.kr/enu/ATR/SI_EN_3_1_1_1. jsp?cid=2025896
} 
kewajiban yang harus dipenuhi. Lapangan golf yang ada di kedua pulau ini juga tidak hanya satu, namun hingga berjumlah lebih dari lima lapangan golf.

Lapangan golf yang ada di kedua pulau ini ternyata memiliki beberapa persamaan yang mendasar. Bali National Golf Club dan Jeju Country Club merupakan dua lapangan golf bertaraf internasional yang diketahui memiliki beberapa persamaan. Kedua lapangan golf ini dapat dikatakan sebagai lapangan golf terbaik yang ada di provinsinya. Kedua lapangan golf ini juga sama-sama memiliki latar belakang pemandangan yang indah yaitu sebuah pemandangan gunung berapi dan laut. Jika di Bali National Golf Club para wisatawan dapat melihat pemandangan Gunung Agung yang indah, dari Jeju Country Club dapat terlihat pemandangan Gunung Halla.

Sebagai lapangan golf yang bertaraf internasional, lapangan golf Bali National GolfClub dan Jeju Country Club memiliki fasilitas yang juga cukup lengkap. Namun jika dilihat secara lebih detail kembali, kedua lapangan golf ini ternyata memiliki sedikit perbedaan dalam bidang fasilitas yang ditawarkan. Jika di Bali National Golf Club menawarkan beberapa fasilitas menarik seperti disediakannya sebuah villa untuk wisatawan yang ingin menginap dan juga terdapat sebuah paket spesial untuk perayaaan sebuah pesta pernikahan hingga paket bulan madu. Sedangkan di Jeju Country Club tidak disediakan fasilitas tersebut, namun di lapangan golf ini wisatawan bisa lebih merasakan kebudayaan Korea yang kental dengan berkunjung ke Tea House yang disediakan di lapangan golf ini. ${ }^{5}$

\section{4) Wisata Bahari}

Menjadi sebuah provinsi kepulauan membuat pulau Bali dan pulau Jeju memiliki keindahan laut yang beraneka ragam. Karena berbentuk sebuah pulau, pantai yang ada di kedua pulau ini sangat beragam dengan keunikannya masing-masing. Dari sekian banyak wisata bahari yang ditawarkan ada terdapat beberapa destinasi wisata yang sama dan berbeda dari kedua pulau ini.

\section{a. Pantai}

Sebagai provinsi kepulauan, pantai merupakan suatu tempat yang sangat mudah ditemui di Bali dan Jeju. Kedua pulau ini sama-sama memiliki

\footnotetext{
www.balinationalgolf.com/facilities/
}

banyak pantai indah yang tersebar hampir di seluruh wilayahnya. Meskipun berjumlah banyak, setiap pantai yang ada di kedua pulau ini memiliki keunikannya masing-masing. Pantai-pantai yang ada di kedua pulau ini juga menawarkan kegiatan-kegiatan yang membuat tempat wisata ini semakin istimewa. Surfing, snorkling, diving, dan kegiatan menarik lainnya dapat dilakukan di kedua pulau ini.

Pantai Kuta merupakan pantai yang paling terkenal di Pulau Bali dan dapat dikatakan sebagai ikon dari pulau ini (Rijal, 2013: 15). Bahkan ada ungkapan yang mengatakan bahwa belum ke Bali jika belum ke pantai Kuta. Pantai yang berada di kabupaten Badung ini merupakan pantai yang pertama kali ditunjukkan untuk tempat wisata di pulau ini. Di depan pantai ini terdapat sebuah jalan yang kini cukup ramai dikunjungi oleh para wisatawan. Di jalan ini banyak dibuka cafe, restoran hingga mall.

Sama dengan pantai Kuta, pantai Woljeongri merupakan pantai yang paling terkenal di Jeju. Pantai ini juga merupakan pantai pasir putih yang ramai didatangi oleh wisatawan. Sepanjang jalan di depan pantai ini juga banyak di buka cafe cantik yang menghadap langsung ke arah pantai Woljeongri. Cafe-cafe inilah yang menjadi salah satu daya tarik dari pantai ini.

Namun jika dilihat secara lebih detail, kedua pantai ini memiliki beberapa perbedaan. Jika dilihat dari popularitasnya di taraf internasional, pantai Kuta dapat dikatakan jauh lebih unggul dibandingkan dengan pantai Woljeongri.

Sebagai ikon Pulau Bali, pantai Kuta tentu mempunyai daya tarik yang berbeda dengan pantai Woljeongri. Di pantai Kuta, kegiatan yang dapat dilakukan lebih banyak dibandingkan di pantai Woljeongri. Selain jalan-jalan santai mengelilingi pantai Kuta, wisatawan juga dapat berselancar disini karna ombaknya yang cukup bagus untuk berselancar. Berbeda dengan pantai Woljeongri yang ombaknya tidak terlalu tinggi untuk dijadikan tempat berselancar. Namun jika hanya ingin jalan-jalan sambil menikmati keindahan pantai yang tenang, pantai Woljeongri lebih unggul dibandingkan dengan pantai Kuta. Jalan di sekitar pantai dengan cafe-cafe cantiknya membuat siapa saja yang datang kesini jatuh hati dengan keasrian dari pantai Woljeongri. ${ }^{6}$

\footnotetext{
${ }^{6}$ wwws://allaboutjeju.com/2014/06/17/rainy-day-woljeongbeach-cafe-street/
} 


\section{b. Bermain Kano}

Jika ingin menikmati suasana pantai dengan cara yang santai, bermain kano merupakan pilihan yang cocok untuk dilakukan di kedua pulau ini. Kedua pulau ini sama-sama memiliki wisata kano di pantai unggulan mereka. Jika ingin bermain kano di Pulau Bali, wisatawan bisa datang ke kawasan pantai Sanur, jika ingin merasakan bermain kano di Pulau Jeju, wisatawan dapat langsung datang ke pantai Weoljeongri.

Meski sama-sama menawarkan kano untuk disewakan para pengunjung, kedua tempat ini tentunya memiliki beberapa perbedaan. Perbedaan ini terlihat dari fasilitas yang diberikan oleh pengelola tempat wisata. Jika di pantai Sanur, sistem penyewaan kano tersebut dibatasi hanya 30 menit, sedangkan penyewaan kano di pantai Sanur tidak dibatasi oleh waktu. Namun fasilitas lainnya yang berbeda yaitu dari segi keamanan. Di pantai Sanur, para penyewa hanya disediakan kano dan alat dayungnya saja untuk bermain, namun di pantai Weolnjeong-ri, pengelola juga menyediakan pelampung keselamatan untuk para pengunjungnya.

\section{c. Berselancar}

Olahraga berselancar mungkin menjadi tujuan utama para pengunjung yang datang ke kedua pulau ini. Pulau Bali dan Pulau Jeju sama-sama memiliki pantai dengan ombak yang cocok untuk dijadikan tempat berselancar. Tidak hanya ombak pantainya yang mendukung, cuaca yang ada di kedua pulau ini juga mendukung untuk melakukan kegiatan berselancar. Di Pulau Jeju, wisatawan yang ingin berselancar dapat mengunjungi pantai Jungmun, Sagye, Weoljeong dan Iho Tewoo. Jika berkunjung ke Bali, wisatawan dapat mengunjungi pantai PadangPadang, Uluwatu, Balangan, Dreamland, dan lain sebagainya. Semakin banyaknya peminat olahraga air ini membuat pengelola wisata melihat peluang wisata baru yaitu sekolah surfing.

Menjadi tempat favorit untuk berselancar, kedua pulau ini juga memiliki beberapa perbedaan. Jika di Pulau Bali, karena cuaca dan iklim yang mendukung setiap tahunnya, para peselancar dapat terus berselancar sepanjang tahun. Walaupun musim hujan turun di pulau ini, ombak di Bali terkadang masih bersahabat untuk dijadikan tempat berselancar meskipun harus lebih berhati-hati. Berbeda dengan Bali, jika cuaca di Jeju sedang tidak bersahabat, angin kencang yang terus menerus datang tidak akan memperbolehkan para wisatawan untuk berselancar. Tidak seperti di Bali, sekolah berselancar di Jeju tidaklah begitu banyak. Hanya terdapat dua sekolah berselancar di pulau ini. Sekolah tersebut adalah Jeju Surfing School di Jungmun-dong dan Bagus Surfing School di Sagye-ri, Andeok-myeon.

\section{5) Wisata Kuliner}

Wisata kuliner kini merupakan salah satu wisata yang sedang banyak dilakukan oleh masyarakat. Jika mengunjungi suatu tempat wisata, tidak lengkap rasanya jika tidak mencicipi makanan khas dari daerah tersebut. Pulau Bali dan Pulau Jeju merupakan sebuah tempat wisata yang banyak memiliki makanan khas dari daerahnya. Sebagai provinsi yang berbentuk kepulauan, makanan khas dari kedua pulau ini hampir sama yaitu banyak dari hasil laut. Hasil laut yang beraneka ragam ini diolah dengan menggunakan bumbu khas dari masing-masing daerah. Selain olahan dari hasil laut, kedua pulau ini sama-sama mempunyai menu utama lainnya yaitu dari olahan daging babi. Daging babi dari kedua pulau ini merupakan salah satu makanan khas yang menjadi andalan di kedua provinsi ini. Meski sama-sama berasal dari olahan hasil laut dan daging babi, cara peyajian dan bumbu lainnya yang membedakan dari makanan khas kedua pulau ini. Jika di Jeju, seluruh olahan hasil laut biasanya disajikan dengan cara dicampur dalam satu wadah dan diberikan bumbu pelengkap, disebut dengan Haemul-jeongol (seafood hot pot). Berbeda dengan yang ada di Jeju, olahan khas hasil laut yang ada di Bali disajikan dengan cara terpisah.

Sebagian besar hasil olahan hasil laut yang ada di Bali juga banyak yang disajikan dengan cara dibakar, berbeda dengan di Jeju yang lebih banyak disajikan dengan berbentuk sup. Daging babi yang menjadi makanan khas dari dua pulau ini juga disajikan dengan cara yang berbeda. Jika daging babi di Jeju disebut dengan Heuk Dwaeji atau Babi Jeju Hitam, di Bali sajian ini diolah dengan nama Babi Guling atau Babi Panggang. Di Jeju, babi hitam tersebut disajikan dengan cara dibakar, sedangkan di Bali, daging babi itu disajikan dengan cara dipanggang secara utuh (Ulung, 2009 : 25). 


\section{KESIMPULAN}

Indonesia dan Korea Selatan merupakan dua negara yang memiliki sektor pariwisata yang cukup terkenal di seluruh dunia, yaitu pulau Bali di Indonesia dan pulau Jeju di Korea. Dengan tingkat popularitas yang tinggi di kancah internasional, kini sebagian besar fasilitas wisata yang ada di kedua pulau ini sudah bertaraf internasional.

Kedua pulau wisata ini ternyata merupakan salah satu sister province yang ada di dunia. Sister Province merupakan sebuah provinsi saudara yang saling dikaitkan satu sama lain karena memiliki beberapa persamaan. Pulau Bali dan Pulau Jeju sebagai salah satu wisata unggulan negaranya ini diketahui memiliki beberapa persamaan dalam bidang pariwisatanya. Selain itu, kedua pulau ini juga memiliki beberapa perbedaan dari sejarah awal dan jenis wisatanya. Persamaan dan perbedaan tersebut yang menjadikan kedua pulau ini memiliki keunikannya masing-masing.

Perkembangan awal pariwisata Pulau Bali dan Pulau Jeju dimulai ketika orang asing yang berasal dari negara lain datang dan meilihat langsung kedua pulau ini. Dengan segala keindahan alam dan keramah-tamahan penduduk lokalnya, banyak dari mereka yang jatuh hati dan terpesona dengan pulau ini. Karya tulis hingga karya lukispun banyak yang diciptakan untuk menggambarkan keindahan kedua pulau ini. Hingga pada akhirnya buku hasil catatan pengunjung asing itulah yang membawa Bali dan Jeju dikenal hingga ke seluruh dunia.

Pulau Bali dan Pulau Jeju juga memiliki beberapa persamaan dan perbedaan yang beragam. Persamaan dan perbedaan dari Bali dan Jeju dapat dilihat dari sejarah awal dimulainya pariwisata dan jenis wisata yang ditawarkan. Jika dilihat secara sekilas, kedua pulau ini memang mirip dalam segi perkembangan pariwisatanya, namun jika dilihat secara lebih teliti, akan ditemukan beberapa perbedaan. Persamaan dan perbedaan inilah yang menjadikan kedua pulau ini memiliki ciri khas tersendiri.

\section{DAFTAR PUSTAKA}

Bali Glory. (2015). Sejarah Singkat Tentang Pulau Dewata. www.id.baliglory.com/2015/06/balipulau-dewata.html.
Dinar, Nancy. (2013). Korea A to Z. Jakarta: Gramedia Pustaka Utama.

Ekaristi, Maria \& Agung Bawantara. (2009). Jalanjalan Bali. Jakarta: Gagas Media.

Gede, Manggala. (2015). 3 Keindahan Sejarah Bhineka Tunggal Ika yang Perlu Kita Ingat. www.medium.com/@gedemanggala/3keindahan-sejarah-bhinneka-tunggal-ika-yangperlu-kita-ingat-d5b067971aec\#.bhnoy177z .

Jeju Special Self-Govermning Province. (2015). Three Abundancies, Three Lacks \& Three Treasures. www://english.jeju.go.kr/index.php/contents/ culture-nature/samda/intro/explain.

Korea Tourism Organization. (2015). Introduction of Jeju-do. www://english.visitkorea.or.kr:1001/ enu/si/si_en_3_6.jsp?cid=256109.

Pemerintah Provinsi Bali. (2010). Geographi.www. baliprov.go.id/geographi

Pemerintah Provinsi Bali. (2010). Agama, Adat, dan Budaya. www.baliprov.go.id/id/agama--adat-dan-budaya.

Rifa'i, Ryan. (2015). Ketertarikan Orang Korea Terhadap Obyek Pariwisata Unggulan di Daerah Istimewa Yogyakarta. TugasAkhir. Tidak dipublikasikan. Yogyakarta: Universitas Gadjah Mada.

Rosalina, Deasy. (2013). Best of Jeju dan Sekitarnya. Jakarta: Elex Media Komputindo (EMK).

Sugihastuti. (2007). Bahasa Laporan Penelitian. Yogyakarta: PustakaPelajar.

SeputarPengetahuan. (2015). 20 Pengertian Pariwisata Menurut Para Ahli Terlengkap. www.seputarpengetahuan.com/2015/12/20pengertian-pariwisata-menurut-para-ahliterlengkap.html.

Tanjung, Elvira Fidelia. (2011). Annyeong Korea. Jakarta: Gagas Media.

Ulung, Gagas. (2009). Enjoying Bali. Jakarta: Gramedia Gagas Utama.

Yang, Yeong Hoon. (2008). Perdamaian Sifat Asli Pulau Misterius di Pulau Jeju. South Korea: Gimmyoung. 